\title{
Towards a test to verify that wood has been heat-treated to the ISPM15 standard
}

\author{
I.I. Iline, M.A. Novoselov, N.K. Richards and C.B. Phillips \\ AgResearch, Lincoln, Private Bag 4749, Canterbury 8140, New Zealand \\ All the authors belong to the Better Border Biosecurity (B3) research collaboration \\ Corresponding author: ilia.iline@agresearch.co.nz
}

\begin{abstract}
International trade of wood, including dunnage, is a well-known pathway for spreading diseases and wood-boring insects between countries. To mitigate this risk, the International Standard for Phytosanitary Measures No. 15 (ISPM15) states that wood packaging materials must be heated to a minimum of $56^{\circ} \mathrm{C}$ for $30 \mathrm{~min}$. However, it is difficult to confirm that wood has been properly heat-treated. After preliminary investigations of 12 enzymes and 3 sugars from pine xylem, experiments focused on malate dehydrogenase $(\mathrm{MDH})$ and fructose. Samples from the surfaces of heat-treated Pinus radiata wood exhibited decreased $\mathrm{MDH}$ activity and increased fructose concentration. However, samples from $5 \mathrm{~mm}$ deeper in the profile of heated wood showed similar MDH activity to unheated wood, but contained relatively lower fructose concentrations. There is potential to exploit heatinduced changes in $\mathrm{MDH}$ activity and fructose concentration to develop a quick, easily-used assay for verifying compliance of wood packaging materials with ISPM15.
\end{abstract}

Keywords heat treatment, ISPM15, Pinus radiata, xylem metabolites, malate dehydrogenase, fructose, wood packaging material.

\section{INTRODUCTION}

Wood packaging material (WPM), including pallets, crates and dunnage (used to brace cargo), is a primary pathway for accidentally moving bark beetles and wood-boring insects between countries (Brockerhoff et al. 2006; Zahid et al. 2008; Haack et al. 2014). Each year in the United States, wood-boring insects cost an estimated $\$ 1.7$ billion in local government expenditure and approximately $\$ 830$ million in lost residential property values (Aukema et al. 2011). They can also have irreversible impacts on native species and ecosystems (Poland \& McCullough 2006).

To reduce biosecurity risks from WPM, the International Plant Protection Convention (IPPC 2002) developed a set of globally accepted measures called International Standards for
Phytosanitary Measures No. 15 (ISPM15). The standard stipulates that WPM must consist only of debarked wood to reduce risks of posttreatment reinfestation (Haack \& Petrice 2009), although small pieces of bark may remain if they are less than $3 \mathrm{~cm}$ wide. WPM wider than $6 \mathrm{~mm}$ must be heat-treated or methyl bromide fumigated (IPPC 2013). Heating must reach a minimum temperature of $56^{\circ} \mathrm{C}$ throughout the wood profile, including the core, for a minimum of 30 continuous minutes (IPPC 2013). By October 2013, more than 78 countries had implemented ISPM15 (Haack et al 2014).

Upon treatment to the ISPM15 standard, WPM is stamped with a readily identifiable mark. National Plant Protection Organisations (NPPOs) 
are responsible both for authorising use of the mark by treatment providers, and for regularly inspecting and auditing the providers' procedures (IPPC 2013). Sub-standard treatment, treatment failure and fraudulent use of the ISPM15 mark are all possible, thus a diagnostic test for verifying that WPM has been heat-treated in accordance with ISPM15 would be helpful for NPPOs. To develop such a test, it is necessary to identify one or more wood metabolites that consistently vary between unheated and heated wood.

Various enzymes and sugars have been detected in fresh wood samples (Sagisaka 1972; Haissig \& Schipper 1978; Moeller et al. 2006), but there have been few studies of either dry or ISPM15treated wood. In general, heating to $56^{\circ} \mathrm{C}$ is usually insufficient to completely inactivate enzymes, though it may reduce their activity (Anderson 2002; Gonzalez et al. 2011; Iline et al. 2013). Heating, however, should cause sap to move within xylem, thus metabolite concentrations in different parts of the wood profile may change with heat-treatment. Also, enzymes near the wood surface might receive elevated temperatures for longer than enzymes in the core, thus suffering greater thermal inactivation.

This paper investigates enzymes and sugars in xylem of Pinus radiata for their potential utility in verifying that WPM has been ISPM15 heattreated. Methods similar to those recently applied to develop other tests for verifying compliance have been used (Iline et al. 2013; Novoselov et al. 2013; Phillips et al. 2013; Phillips et al. 2014).

\section{MATERIALS AND METHODS}

Two experiments were conducted. The first investigated the activity of 12 enzymes and the concentrations of three sugars in unheated $P$. radiata samples $0-2$ weeks and 1-2 months after the wood was harvested. It also compared two sample maceration methods. Based on these results, the second experiment used one sample maceration method to compare malate dehydrogenase (MDH) activity and fructose concentration between unheated and heated samples. Experiment Two measured the metabolites both 1 month and 2 months after the wood was harvested. In the 2-month-old wood, samples were obtained from two locations in the wood profile and compared. The enzymes and sugars chosen from the literature for investigation in Experiment One are listed in Table 1 with key references.

\section{Pinus radiata collection, preparation and storage}

Two branches (diameter 3-4 cm) were hand-sawn from each of five live $P$. radiata trees (5-7 $\mathrm{m}$ tall) about $1 \mathrm{~m}$ from the ground. The branches were cut into two $10 \mathrm{~cm}$ long segments and the bark was stripped from the distal end of each segment using a knife. Xylem was exposed by scraping the knife longitudinally along the exposed surface to remove the sticky cambium layer. Removing the cambium simulated milled timber, which usually also lacks cambium. The segments were labelled and stored in the laboratory, open to the air and at ambient temperature, from 1 week to 3 months prior to experiments.

\section{Sample preparation}

Wood shavings (30-50 mg/sample) were collected from the distal ends of 20 branch segments that had been stored for either $0-2$ weeks or 1-2 months by scraping the sawn surface with a sharp knife to obtain fine shavings $(<1 \mathrm{~mm})$. Liquid nitrogen $(10-12 \mathrm{ml})$ was poured into a porcelain mortar, shavings were immediately added, liquid nitrogen was allowed to evaporate, then $0.1 \mathrm{M}$ TAE buffer ( $\mathrm{pH} 7.8$ ) or $0.1 \mathrm{M} \mathrm{Na}$-acetate (pH 5.0) (Table 1) was added to the mortar using an $11: 1$ ratio of extraction buffer volume $(\mu \mathrm{l})$ to sample weight $(\mathrm{mg})$, typically $330-550 \mu \mathrm{l}$. This was enough to dampen all the shavings.

The two sample maceration procedures compared in Experiment One involved either manually macerating each wood sample or using a bead mill. To manually macerate samples, the buffer-sample mixture was macerated with a porcelain pestle. For the bead mill method, the buffer-sample mixture was put into a specialised steel tube with either one or two $7 \mathrm{~mm}$ steel balls and shaken at $50 \mathrm{~Hz}$ for 1 or 2 min using a TissueLyser LT (Qiagen).

After maceration, samples were transferred by spatula into a $1.7 \mathrm{ml}$ Eppendorf tube and centrifuged for $30 \mathrm{~s}$ at $9000 \mathrm{rpm}$. The clear supernatant $(\mathrm{ca} 70 \mu \mathrm{l})$ was transferred by pipette 
into a $0.2 \mathrm{ml}$ tube and kept chilled to minimise enzyme inactivation (Haissig \& Schipper 1978). Supernatants were assayed within $1 \mathrm{~h}$ of centrifugation. For all assays, $7 \mu \mathrm{l}$ of supernatant was added to an equal volume of stain (described below) in a $0.2 \mathrm{ml}$ microtube (Axygen, California, USA, thin wall clear, PCR-02-C).

\section{Activity staining of enzymes}

Recipes for activity staining of most enzymes were modified from Manchenko (2003). Exceptions were activity stains for coniferyl and cinnamyl dehydrogenases, which used coniferyl alcohol or cinnamyl alcohol (Halpin et al. 1992; Sauter \& Kende 1992; Pandey et al. 2011). To most recipes, $0.1 \%$ Triton $\mathrm{X}-100$ was added, and NBT was replaced with MTT and PMS with mPMS (Phillips et al. 2013, 2014). Results were evaluated after staining for $30 \mathrm{~min}$.

\section{Evaluation of sugar concentration}

Glucose, fructose and sucrose were assayed using methods based on Hoch et al. (2002). The glucose assay measures glucose only, but the fructose assay measures the combined concentration of fructose and glucose, and the sucrose assay measures the combined concentration of sucrose and glucose (Hoch et al. 2002). Preliminary tests indicated that glucose was present only in low concentrations in these samples so, for brevity, the latter two assays are referred to as the 'fructose test' and the 'sucrose test'. Recipes were modified by adding $0.1 \%$ Triton X-100 and replacing NBT with MTT and PMS with mPMS (Phillips et al. 2013, 2014). Results were evaluated after staining for $5 \mathrm{~min}$.

\section{Experiment One}

The 12 enzymes and three sugars listed in Table 1 were each studied in a minimum of five samples chosen from 10 unheated $P$. radiata samples taken from two segments of five branches. Usually only metabolites that showed activity in 0-2 week-old samples were also assayed in 1-2 month-old samples. Sample maceration methods were compared using 3-5 samples per metabolite.

\section{Experiment Two}

Samples studied were from two $10 \mathrm{~cm}$ long segments from each of five branches collected from five different live $P$. radiata. After 1 month of storage, one segment from each branch was heated in an incubator at $56^{\circ} \mathrm{C}$ for $1.5 \mathrm{~h}$ to simulate ISPM15, and the other was left as an untreated control. As the core temperature of the samples was unable to be measured, $1.5 \mathrm{~h}$ of heating was used to ensure the required core temperature was achieved. Immediately after heat-treatment, shavings were obtained from control and treated samples and prepared using the manual maceration method. Supernatants were tested for $\mathrm{MDH}$ and fructose.

Following a second month of storage, the same branch segments were re-tested for $\mathrm{MDH}$ and fructose. To compare the effect of heat treatment on metabolites in xylem situated at the wood's sawn surface with those situated below its sawn surface, a $5 \mathrm{~mm}$ thick section was hand-sawed off the distal end of each segment, then surface and sub-surface shavings were tested separately. Hand sawing was conducted slowly to minimise frictional heating of the timber.

\section{Measurement of colour reaction}

Photos were taken after $5 \mathrm{~min}$ for the fructose test, and after $30 \mathrm{~min}$ for the $\mathrm{MDH}$ test, then processed by ImageJ as described by Phillips et al. (2013). Optical density (OD) was used to estimate the intensity of the staining reaction (Luo et al. 2010).

\section{Statistical analysis}

Results from treated and untreated samples obtained from the same branch were compared using Student's t-test for paired samples with the statistical package $\mathrm{R}$ version 3.0.2 ( $\mathrm{R}$ Core Team 2012). Graphs were prepared using $R$ and the $R$ package 'ggplot2' (Wickham 2009).

\section{RESULTS}

\section{Experiment One}

The manual sample maceration method gave similar sugar concentration results to the bead mill method, but higher enzyme activity (data not shown). Thus, results are provided only from manually macerated samples.

Four of the twelve enzymes tested, malate dehydrogenase $(\mathrm{MDH})$, peroxidase, coniferyl and cinnamyl alcohol dehydrogenases, showed 
activity in 0-2 week old samples, but $\mathrm{MDH}$ was the only active enzyme remaining in 1-2 month old samples (Table 1). Coniferyl alcohol dehydrogenase was not tested in 1-2 month old samples due to unavailability of chemicals (Table 1). Glucose, fructose and sucrose were all detected in samples of both ages, although fructose gave the most consistent and strongest staining. Thus, $\mathrm{MDH}$ and fructose were further investigated in Experiment Two.

\section{Experiment Two}

In the 1-month-old samples, the mean fructose concentration in heated samples $(0.32 \pm 0.03$; $\mathrm{SE})$ was higher than in untreated samples (0.18 $\pm 0.02 ; \mathrm{t}=7.278, \mathrm{df}=4, \mathrm{P}=0.002$ ) (Figure $1)$. In contrast, mean $\mathrm{MDH}$ activity was lower in heated samples $(0.11 \pm 0.01)$ than in unheated samples $(0.17 \pm 0.01 ; \mathrm{t}=-6.742, \mathrm{df}=4, \mathrm{P}=0.003)$ (Figure 1).

In 2-month-old samples taken from the same part of the wood profile as the 1-month-old samples, results were very similar. Mean fructose concentration was higher $(0.37 \pm 0.09$ cf. $0.18 \pm$ $0.02 ; \mathrm{t}=2.599, \mathrm{df}=4, \mathrm{P}=0.060)$ and mean $\mathrm{MDH}$ activity lower in heated samples $(0.13 \pm 0.01 \mathrm{cf}$. $0.16 \pm 0.03 ; \mathrm{t}=-2.426, \mathrm{df}=4, \mathrm{P}=0.072$ ) (Figure 2, 'External') compared with untreated samples. However, 2-month-old samples obtained from $5 \mathrm{~mm}$ deeper in the wood profile gave different results. Here, mean fructose concentration was lower in heated than untreated samples $(0.14 \pm 0.02$ cf. $0.22 \pm 0.04 ; \mathrm{t}=-3.118, \mathrm{df}=4$, $\mathrm{P}=0.036$ ), and mean $\mathrm{MDH}$ activity was higher

Table 1 Presence of enzyme activity and sugars in xylem of Pinus radiata tested at 2 weeks and 1-2 months after cutting. Markers were identified by a literature review.

\begin{tabular}{|c|c|c|c|c|c|}
\hline \multirow[b]{2}{*}{ Enzyme/sugar } & \multirow[b]{2}{*}{ EC No } & \multirow{2}{*}{$\begin{array}{c}\text { buffer } \\
\text { pH }\end{array}$} & \multicolumn{2}{|c|}{ Activity } & \multirow[b]{2}{*}{ Literature references } \\
\hline & & & $0-2$ wk & $1-2 \mathrm{mo}$ & \\
\hline alcohol dehydrogenase & 1.1.1.1 & 7.8 & - & - & Mansell et al. 1976; Denslow \& Hook 1986 \\
\hline malate dehydrogenase & 1.1.1.37 & 7.8 & + & + & $\begin{array}{l}\text { Shain \& Mackay 1973; Haissig \& Schipper } \\
1978\end{array}$ \\
\hline malic enzyme & 1.1.1.40 & 7.8 & - & - & Ryu \& Na 1983 \\
\hline $\begin{array}{l}\text { 6-phosphogluconate } \\
\text { dehydrogenase }\end{array}$ & 1.1.1.44 & 7.8 & - & & $\begin{array}{l}\text { Sagisaka 1972; Haissig \& Schipper 1978; } \\
\text { Long et al. } 1994\end{array}$ \\
\hline $\begin{array}{l}\text { glucose- } 6 \text {-phosphate } \\
\text { dehydrogenase }\end{array}$ & 1.1 .1 .49 & 7.8 & - & & $\begin{array}{l}\text { Sagisaka 1972; Shain \& Mackay 1973; } \\
\text { Haissig \& Schipper 1972, } 1978\end{array}$ \\
\hline peroxidase & 1.11 .1 .7 & 5.0 & + & - & $\begin{array}{l}\text { Campbell \& Ellis 1992; Luo et al. 2012; } \\
\text { Haissig \& Schipper 1972, 1978; Marjamaa } \\
\text { et al. 2006; Ryu \& Na 1983 }\end{array}$ \\
\hline $\begin{array}{l}\text { coniferyl alcohol } \\
\text { dehydrogenase }\end{array}$ & 1.1.1.194 & 7.8 & + & & $\begin{array}{l}\text { Hawkins \& Boudet 2003; Li et al. 2012; Luo } \\
\text { et al. } 2012\end{array}$ \\
\hline $\begin{array}{l}\text { cinnamyl alcohol } \\
\text { dehydrogenase }\end{array}$ & 1.1.1.195 & 7.8 & + & - & $\begin{array}{l}\text { Anterola \& Lewis 2002; Bedon et al. 2009; } \\
\text { Campbell \& Ellis 1992; Guo et al. 2010; } \\
\text { MacKay et al. 1999; Moeller et al. 2006; } \\
\text { Ramos \& Herrera 2013; Saralde et al. } 2008\end{array}$ \\
\hline$\beta$-D-glucosidase & 3.2.1.21 & 5.0 & - & - & Campbell \& Ellis 1992; Samuels et al. 2002 \\
\hline$\beta$-D-glucuronidase & 3.2 .1 .31 & 5.0 & - & & Bedon et al. 2009 \\
\hline $\begin{array}{l}\text { glucose- } 6 \text {-phosphate } \\
\text { isomerase }\end{array}$ & 5.3.1.9 & 7.8 & - & - & Long et al. 1994 \\
\hline acid phophatase & 3.1.3.2 & 5.0 & - & & Galimova 1987 \\
\hline glucose $^{1}$ & $\mathrm{n} / \mathrm{a}$ & 7.8 & + & + & Fischer \& Hoell 1991, 1992; Hoch \\
\hline fructose $^{1}$ & $\mathrm{n} / \mathrm{a}$ & 7.8 & + & + & et al. 2002, 2003; Stasova \& \\
\hline sucrose $^{1}$ & $\mathrm{n} / \mathrm{a}$ & 7.8 & + & + & Antonova 1989; Wang et al. 2009 \\
\hline
\end{tabular}

${ }^{1}$ Same references for all three sugars. 


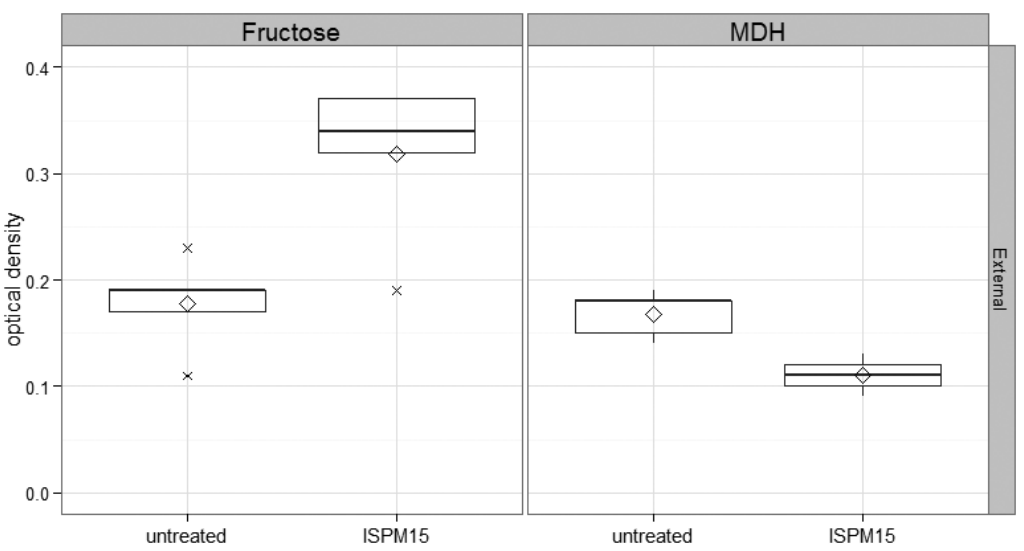

Figure 1 Box plots showing optical densities of tests for fructose concentration and malate dehydrogenase activity in heated and unheated samples taken from the sawn surfaces of wood. The wood had been stored for 1 month. Lower and upper horizontal lines in each box show first and third quartiles, respectively, and the dark central line shows median. Whiskers extend to the highest and lowest values that are within 1.5 times the distance between the first and third quartiles. Diamonds show means and ' $\mathrm{x}$ ' shows outliers.

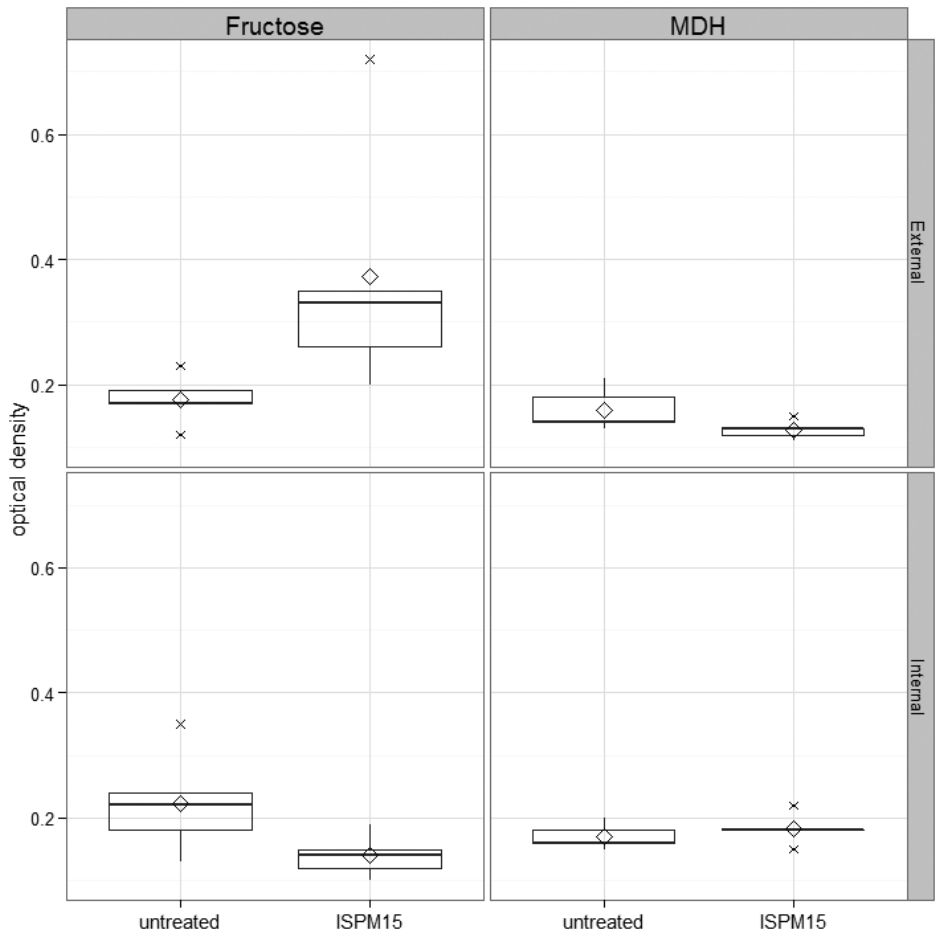

Figure 2 Box plots showing optical densities of tests for fructose concentration and malate dehydrogenase activity in heated and unheated samples taken from the sawn surfaces of wood ('External') and from $5 \mathrm{~mm}$ below sawn surfaces ('Internal'). The wood had been stored for 2 months. Lower and upper horizontal lines in each box show first and third quartiles, respectively, and the dark central line shows median. Whiskers extend to the highest and lowest values that are within 1.5 times the distance between the first and third quartiles. Diamonds show means and ' $x$ ' shows outliers. 
in heated $(0.18 \pm 0.01)$ compared with untreated samples $(0.17 \pm 0.01 ; \mathrm{t}=2.450, \mathrm{df}=4, \mathrm{P}=0.070)$ (Figure 2, 'Internal').

Some ratios between optical densities obtained from different tests and samples clearly separated heated and unheated wood. Using samples taken from sawn surfaces of 1-month-old wood, for example, the mean ratio of $\mathrm{MDH}$ activity to fructose concentration was higher in untreated samples $(1.02 \pm 0.17)$ than in heated samples $(0.38 \pm 0.18 ; \mathrm{t}=-5.834, \mathrm{df}=4, \mathrm{P}=0.004)$ (Figure 3a). Alternatively, fructose concentration measured from sawn surfaces of 2-month-old wood divided by fructose concentration measured from $5 \mathrm{~mm}$ below sawn surfaces of 2-month-old wood was always lower in untreated samples (mean $0.83 \pm 0.08)$ than in heated samples $(2.65 \pm 0.56$; $\mathrm{t}=3.4235, \mathrm{df}=4, \mathrm{P}=0.027$ ) (Figure $3 \mathrm{~b}$ ).

\section{DISCUSSION}

Changes in enzyme activity and sugar concentration in heat-treated wood compared to controls were observed, indicating there is potential to produce an assay for verifying compliance of WPM with ISPM15. A relatively simple sample preparation procedure enabled

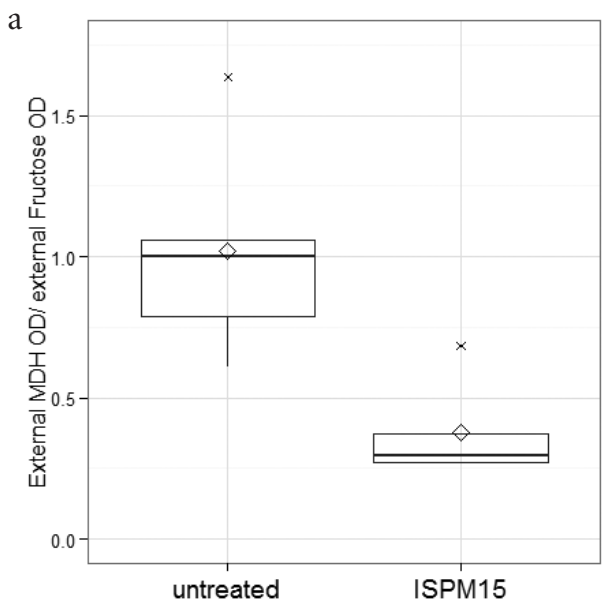

$\mathrm{MDH}$ activity and fructose concentration to be compared between samples, even in wood stored for 2 months. The equipment required is common to most laboratories and the results were reproducible and quantifiable.

Samples macerated in a bead mill gave weaker enzyme activity staining than those macerated manually, possibly because collisions between the steel balls in the bead mill heated the samples and contributed to enzyme inactivation. The sample preparation method using manual maceration of wood ensured samples remained cold, which enabled testing both of enzymes and sugars. This is unlike previous wood sample preparation methods that preclude most enzyme tests because they involve heating (Hoch et al. 2002; Wang et al. 2009).

Activity was detected in only one of twelve enzymes investigated in these $P$. radiata samples, which had been stored for up to 2 months. Other studies have found activity of additional enzymes in wood (cited in Table 1), but these were always obtained from fresh wood samples. It appears that $\mathrm{MDH}$ activity is relatively persistent in stored wood; thus has potential for testing the compliance of WPM with ISPM15.

b

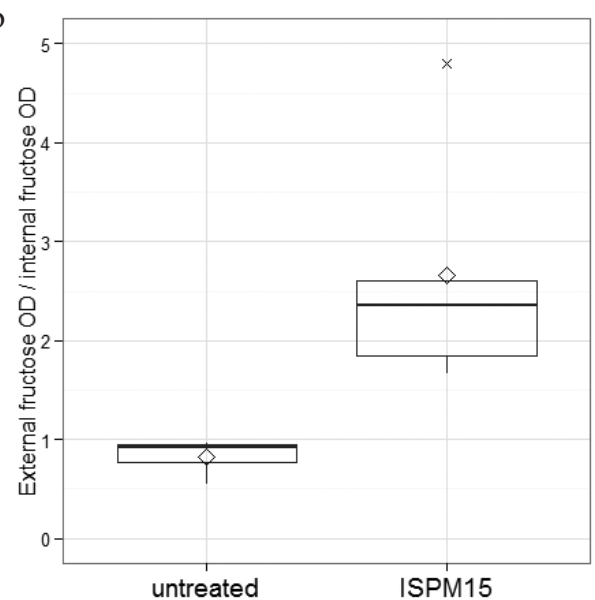

Figure 3 Box plots showing (a) ratio of MDH activity to fructose concentration measured in heated and unheated samples obtained from sawn surfaces of 1-month-old wood, and (b) ratio of fructose concentration measured from sawn surfaces of 2-month-old wood to fructose concentration measured from $5 \mathrm{~mm}$ below sawn surfaces of 2-month-old wood. Lower and upper horizontal lines in each box show first and third quartiles, respectively, and the dark central line shows median. Whiskers extend to the highest and lowest values that are within 1.5 times the distance between the first and third quartiles. Diamonds show means and ' $x$ ' shows outliers. 
Malate dehydrogenase activity was suppressed by the simulated ISPM15 treatment $\left(56^{\circ} \mathrm{C}\right.$ for $1.5 \mathrm{~h}$ ) more in samples obtained from the wood surface than in samples obtained from $5 \mathrm{~mm}$ beneath it. Possibly it took some time for the whole wood profile in the samples to reach $56^{\circ} \mathrm{C}$, with the surface being quickest to heat, thus explaining why $\mathrm{MDH}$ activity was weakest at the surface. Partial inactivation of $\mathrm{MDH}$ at $56^{\circ} \mathrm{C}$ has also been observed in yeast (Kohda et al. 2006).

Compared to controls, samples from the external surfaces of heated wood contained higher concentrations of fructose. Lambertz \& Welling (2010 a,b) also observed increased sugar concentrations on the surface of heated pine wood. The higher fructose concentrations found in xylem on the sawn surface of heated wood than in xylem situated $5 \mathrm{~mm}$ below it might be explained by sap movement. Heating probably causes sap to move through xylem towards the ends of branches, thus producing higher concentrations of sap ingredients at sawn surfaces. WPM treated in steam chambers is highly susceptible to infection by moulds and other fungi if not adequately dried before storage due to heat-induced migration of simple sugars to the surface (Zahid et al. 2008).

Xylem comprises membranes with nanoscale pores (Boutlilier et al. 2014). The large difference in molecular weight between fructose (180) and $\mathrm{MDH}$ (ca 70000) may help explain why fructose concentration, but not $\mathrm{MDH}$ activity, increases at the wood surface after heating. Low molecular weight simple sugars such as fructose would probably migrate more quickly than enzymes through xylem pores.

These results indicate that further research to develop a compliance test for ISPM15 would be worthwhile. Future work would need to investigate a wider range of wood species because ISPM15 is applicable to wood of any species, including tropical to boreal species, softwoods (conifers) and hardwoods (angiosperms) (Haack et al. 2014). It would also need to consider the influences of seasonal fluctuations in wood metabolites. For example, sugars in other Pinus spp. can vary with air temperature, water supply (Stasova \& Antonova 1989) and season (Campbell et al. 1999; Hoch et al. 2002). Similarly, MDH activity varies seasonally in $P$. radiata (Shain \& Mackay 1973). The simulated ISPM15 treatment was adequate for this initial research, but future studies should use wood commercially treated to ISPM15 standard using longer intervals between treatment and testing. This should include woods heated via the different processes allowable under ISPM15, which include kiln-drying, heatenabled chemical pressure impregnation and microwave radiation (IPPC 2013).

\section{ACKNOWLEDGEMENTS}

The research was funded by AgResearch through the Better Border Biosecurity (B3) research collaboration (http://www.b3nz.org). We thank Ecki Brockerhoff (Scion, Christchurch) for coordinating the Pathway Risk Management theme of B3, of which this work was part. We also thank Dr Chikako Van Koten for advice about statistical analysis and Dr Trevor James for helpful comments on the manuscript draft.

\section{REFERENCES}

Anderson JA 2002. Catalase activity, hydrogen peroxide content and thermotolerance of pepper leaves. Scientia Horticulturae 95: 277284.

Anterola AM, Lewis NG 2002. Trends in lignin modification: A comprehensive analysis of the effects of genetic manipulations/mutations on lignification and vascular integrity. Phytochemistry 61: 221-294.

Aukema JE, Leung B, Kovacs K, Chivers C, Britton KO 2011. Economic impacts of nonnative forest insects in the continental United States. PLoS ONE 6(9): e24587. doi:10.1371/ journal.pone.0024587.

Bedon F, Levasseur C, Grima-Pettenati J, Seguin A, MacKay J 2009. Sequence analysis and functional characterization of the promoter of the Picea glauca Cinnamyl Alcohol Dehydrogenase gene in transgenic white spruce plants. Plant Cell Reports 28: 787-800.

Boutillier MSH, Lee J, Chambers V, Venkatesh V, Karnik R 2014. Water filtration using plant xylem. PLoS ONE 9(2): e89934. doi:10.1371/ journal.pone.0089934. 
Brockerhoff EG, Bain J, Kimberley MO, Knížek M 2006. Interception frequency of exotic bark and ambrosia beetles (Coleoptera: Scolytinae) and relationship with establishment in New Zealand and world-wide. Canadian Journal of Forest Research 36: 289-298.

Campbell MM, Ellis BE 1992. Fungal elicitormediated responses in pine cell cultures I. Induction of phenylpropanoid metabolism. Planta 186: 409-417.

Campbell JA, Hansen RW, Wilson JR 1999. Cost-effective colorimetric microtitre plate enzymatic assays for sucrose, glucose and fructose in sugarcane tissue extracts. Journal of the Science of Food \& Agriculture 79: 232-236.

Denslow S, Hook DD 1986. Extraction of alcohol dehydrogenase from fresh root tips of loblolly pine. Canadian Journal of Forest Research 16: 146-148.

Fischer C, Hoell W 1991. Food reserves of Scots pine Pinus sylvestris L. I. Seasonal changes in the carbohydrate and fat reserves of pine needles. Trees 5: 187-195.

Fischer C, Hoell W 1992. Food reserves of Scots pine Pinus sylvestris L. II. Seasonal changes and radial distribution of carbohydrate and fat reserves in pine wood. Trees 6: 147-155.

Galimova IV 1987. Studies in the activity and molecular heterogeneity of acid phosphatase in poplar heterosis hybrids. Fiziologiya i Biokhimiya Kul'turnykh Rastenii 19: 119-124. Gonzalez SL, Lima RCA, Carneiro EBB, Almeida MM, Rosso ND 2011. Pectin methylesterase activity determined by different methods and thermal inactivation of exogenous PME in mango juice. Ciencia e Agrotecnologia 35: 987-994.

Guo DM, Ran JH, Wang XQ 2010. Evolution of the cinnamyl/sinapyl alcohol dehydrogenase (CAD/SAD) gene family: The emergence of real lignin is associated with the origin of bona fide CAD. Journal of Molecular Evolution 71: 202-218.
Haack RA, Britton KO, Brockerhoff EG, Cavey JF, Garrett LJ, Kimberley M, Lowenstein F, Nuding A, Olson LJ, Turner J, Vasilaky KN 2014. Effectiveness of the International Phytosanitary Standard ISPM No. 15 on Reducing Wood Borer Infestation Rates in Wood Packaging Material Entering the United States. PloS ONE 9: e96611 (doi:10.1371).

Haack RA, Petrice TR 2009. Bark- and woodborer colonization of logs and lumber after heat treatment to ISPM 15 specifications: the role of residual bark. Journal of Economic Entomology 102: 1075-1084.

Haissig BE, Schipper ALJr 1972. Easy extraction of enzymes from small amounts of woody tissue. Analytical Biochemistry 48: 129-146.

Haissig BE, Schipper ALJr 1978. How to extract and characterize dehydrogenases from woody plants. U S Forest Service Research Paper NC 159: 1-15.

Halpin C, Knight ME, Grima-Pettenati J, Goffner D, Boudet A, Schuch W 1992. Purification and characterization of cinnamyl alcohol dehydrogenase from tobacco stems. Plant Physiology 98: 12-16.

Hawkins S, Boudet A 2003. 'Defence lignin' and hydroxycinnamyl alcohol dehydrogenase activities in wounded Eucalyptus gunnii. Forest Pathology 33: 91-104.

Hoch G, Popp M, Körner C 2002. Altitudinal increase of mobile carbon pools in Pinus cembra suggests sink limitation of growth at the Swiss treeline. Oikos 98: 361-374.

Hoch G, Richter A, Körner C 2003. Nonstructural carbon compounds in temperate forest trees. Plant, Cell and Environment 26: 1067-1081.

Iline II, Novoselov M, Phillips CB 2013. Proof of concept for a biochemical test that differentiates between heat-treated and nonheat-treated food products. New Zealand Plant Protection 66: 34-39.

IPPC (International Plant Protection Convention) 2002. International Standards for Phytosanitary Measures: Guidelines for Regulating Wood Packaging Material in International Trade, Publ. No. 15. Food and Agriculture Organization of the United Nations, Rome, Italy. 
IPPC (International Plant Protection Convention) 2013. International Standards for Phytosanitary Measures: Revision of ISPM 15, Regulation of Wood Packaging Material in International Trade (2009) Food and Agriculture Organization of the United Nations, Rome, Italy.

Kohda J, Kawanishi H, Suehara KI, Nakano Y, Yano $T$ 2006. Stabilization of free and immobilized enzymes using hyperthermophilic chaperonin. Journal of Bioscience \& Bioengineering 101: 131-136.

Lambertz G, Welling J 2010a. Increase in the content of extractives in Scots pine (Pinus sylvestris L.) during ISPM-15 heat-treatment and correlation with fungal discoloration. Proceedings of the COST E53 Meeting, Bled, Slovenia, 21-23 April 2009. University of Ljubljana, Biotechnical Faculty: EDG Drying Seminar improvement of wood drying quality by conventional and advanced drying techniques. Pp. 2025-2030.

Lambertz G, Welling J 2010b. Changes in extractives of Scots pine (Pinus sylvestris L.) after ISPM 15 heat treatment and their effect on fungal discolouration. Wood Material Science and Engineering 5: 67-72.

Li X, Ma D 2012. Biochemical characterization and identification of a cinnamyl alcohol dehydrogenase from Artemisia annua. Plant Science 193: 85-95.

Long CM, Mulinix CA, Iezzoni AF 1994. Production of a microspore-derived callus population from sweet cherry. Hortscience 29: 1346-1348.

Luo S, Li J, Liu X, Lu Z, Pan W, Zhang Q, Zhao Z 2010. Effects of six sugars on the longevity, fecundity and nutrient reserves of Microplitis mediator. Biological Control 52: 51-57.

Luo Z, Feng S, Pang J, Mao L, Shou H, Xie J 2012. Effect of heat treatment on lignification of postharvest bamboo shoots (Phyllostachys praecox $f$. prevernalis). Food Chemistry 135: 2182-2187.

MacKay J, Presnell T, Jameel H, Taneda H, O’Malley D, Sederoff R 1999. Modified lignin and delignification with a CAD-deficient loblolly pine. Holzforschung 53: 403-410.
Manchenko GP 2003. Handbook of detection of enzymes on electrophoretic gels, 2 nd edn. CRC Press, Florida, USA.

Mansell RL, Babbel GR, Zenk MH 1976. Multiple forms and specificity of coniferyl alcohol dehydrogenase from cambial regions of higher plants. Phytochemistry 15: 1849-1853.

Marjamaa K, Kukkola E, Lundell T, Karhunen P, Saranpaa P, Fagerstedt KV 2006. Monolignol oxidation by xylem peroxidase isoforms of Norway spruce (Picea abies) and silver birch (Betula pendula). Tree Physiology 26: 605-611.

Moeller R, Koch G, Nanayakkara B, Schmitt U 2006. Lignification in cell cultures of Pinus radiata: activities of enzymes and lignin topochemistry. Tree Physiology 26: 201-210.

Novoselov MA, Iline II, Phillips CB 2013. How fresh is that frass? New Zealand Plant Protection 66: 376 (abstract only).

Pandey B, Pandey VP, Dwivedi UN 2011. Cloning, expression, functional validation and modeling of cinnamyl alcohol dehydrogenase isolated from xylem of Leucaena leucocephala. Protein Expression \& Purification 79: $197-$ 203.

Phillips CB, Iline II, Richards NK, Novoselov MN, McNeill MR 2013. Development and validation of a quick, easily used biochemical assay for evaluating the viability of small immobile arthropods. Journal of Economic Entomology 106: 2006-2019. doi:10.1603/ EC13028.

Phillips CB, Iline II, Novoselov M, Richards NK 2014. Potential to exploit postmortem enzyme degradation for evaluating arthropod viability. Applied Entomology and Zoology doi: 10.1007/s13355-014-0264-0.

Poland TM, McCullough DG 2006. Emerald ash borer: Invasion of the urban forest and the threat to North America's ash resource. Journal of Forestry April/May: 118-124.

$\mathrm{R}$ Core Team 2012. R: A language and environment for statistical computing. $\mathrm{R}$ Foundation for Statistical Computing, Vienna, Austria. ISBN 3-900051-07-0, http://www.R-project.org/. 
Ramos P, Herrera R 2013. Anatomical changes of xylem cells in stem of Pinus radiata seedlings exposed to inclination and ethylene. Biologia Plantarum 57: 525-530.

Ryu JB, Na CS 1983. Isozyme analysis with foliage of 4 pine species. Research Report of the Forest Genetics Research Institute 19: 15-19.

Sagisaka S 1972. Decrease of glucose 6-phosphate and 6-phosphogluconate dehydrogenase activities in the xylem of Populus gelrica on budding. Plant Physiology 50: 750-755.

Samuels AL, Rensing KH, Douglas CJ, Mansfield SD, Dharmawardhana DP, Ellis BE 2002. Cellular machinery of wood production: Differentiation of secondary xylem in Pinus contorta var. latifolia. Planta 216: 72-82.

Saralde TCJr, Peralta PN, Peszlen I, Kasal B 2008. Mechanical properties of lumber from partially CAD-deficient loblolly pine (Pinus taeda). Wood and Fiber Science 40: 657-662.

Sauter M, Kende H 1992. Levels of beta-glucan and lignin in elongating internodes of deepwater rice. Plant \& Cell Physiology 33: 1089-1097.
Shain L, Mackay JFG 1973. Seasonal fluctuation in respiration of aging xylem in relation to heartwood formation in Pinus radiata. Canadian Journal of Botany 51: 737-741.

Stasova VV, Antonova GF 1989. Low-molecular carbohydrates of the developing xylem of Pinus sylvestris shoots. Lesovedenie 6: 84-89.

Wang W, Sun W, Wang Y, Zu YG, Hu Y 2009. Influences of sample preparation methods on determination of soluble sugars in trunk of Korean pine by HPLC method. Journal of Northeast Forestry University 37: 76-78.

Wickham H 2009. ggplot2: elegant graphics for data analysis. Springer, New York.

Zahid MI, Grurinovic CA, Walsh DJ 2008. Quarantine risks associated with solid wood packaging material receiving ISPM15 treatments. Australian Forestry 71: 287-293. 